\title{
The politics of redistribution in local government
}

\author{
BAS DENTERS
}

Faculty of Public Policy and Public Administration, University of Twente, Enschede, The Netherlands

\begin{abstract}
This paper deals with the politics of redistribution in local government. Traditionally, it has been assumed that redistributive policies are crucial in electoral competition and party politics, both in national and local political systems. From this perspective, differences in local competition and party systems are essential to an explanation of local redistributive efforts. Peterson (1981), however, claims that redistributive policies are excluded from the local agenda because they impair local economic prosperity. These policies are therefore not conceived as instruments in the vote-maximizing strategies of local political parties. In this paper, hypotheses on the impact of party competition and party politics on local redistribution are formulated and tested on data for 342 Dutch municipalities. The results show that, contrary to what would be expected from Peterson's perspective, municipal redistributive efforts were related to electoral competitiveness and the party system. The proposed model, however, proved to be unsatisfactory in accurately predicting the direction of the effects of these explanatory variables. These results suggest that, rather than abandoning the study of local redistribution as a non-issue in subnational politics, an effort should be made to develop a better theoretical understanding of the ways in which competition and party politics shape these policies.
\end{abstract}

\section{Introduction}

With the introduction of universal suffrage in western democracies it was hypothesized that the political equality inherent in the one-man-one-vote rule would affect social and economic equality. The logic underlying of this this argument implies that politicians, being dependent on the popular vote, will adopt policies to attract the support of as many voters as possible: 'Thus the equality of franchise in a democratic society creates a tendency for government action to equalize incomes by redistributing them from a few wealthy persons to many less wealthy ones' (Downs 1957: 198). These transfers of 'income' may be either in money or in kind (as when a government delivers free goods or services). Redistributive policies, therefore, are government programmes in which the net income (the balance of all benefits and costs, both in money and in kind) of lower income groups relative to more prosperous groups is increased.

In the analysis of state and local policies, propositions similar to the Downsian redistribution hypothesis have been advanced. Redistributive issues are thought to be crucial in subnational politics too. In an assessment of studies of state and local politics, for example, Jacob \& Lipsky stress the general importance of redistributive policies: 'The distribution of benefits or sanctions is perhaps the most significant output dimension for political scien- 
tists, since much of the conflict preceding adoption of a program is not about whether it should be embarked upon but who will pay and who will benefit' (Jacob \& Lipsky 1971: 19). In this statement, the key issues in both national and subnational politics concern the classic Laswellian questions of who gets what, when and how? Furthermore in analyses of state and local redistribution, Downs' redistribution hypothesis is, implicitly or explicitly, typically taken as a starting-point. Gray, for example, in a paper on state policies, puts it this way: "Have-nots" constitute the largest pool of potential voters. Party-leaders, recognizing competition as a threat to the attainment of office will adopt a policy-strategy directed towards the "have-nots" (Gray 1976: 239-240). Along these and similar lines, many scholars from both the US and Europe have conducted studies focussing on the politics of redistribution in subnational government. Almost all of these studies, in one way or another, hypothesize effects of party competition and party politics on the level of local redistribution (as with the hypothesis that, the more intense partycompetition, the more redistributive local policies will tend to be). ${ }^{1}$

In his provocative book City Limits (1981), the American political scientist Peterson challenges this prevalent approach. According to Peterson (1981: 22) 'cities seek to improve their market position, their attractiveness as a locale for economic activity'. If the local economy prospers, unemployment is low, labour is scarce and wages increase, land values rise, tax revenues increase and local government is therefore able to provide a wider range of goods and services. Local politicians, motivated by a sense of community responsibility, try to promote the market position of their municipality by adopting policies conducive to economic growth. On the other hand, they try to avoid policies that impair the city's economic interests. Redistributive policies, providing benefits for low-income citizens which are payed for by taxes on the wealthy, are held to damage the city's economic prospects. Peterson concludes that: "[r]edistribution is seldom a significant aspect of local government operations, and therefore the issue is largely excluded from the local political agenda' (1981: 167). In other words, redistribution is essentially 'beyond the city limits'. ${ }^{2}$ Therefore, Peterson's argument implies that national and subnational politics are qualitatively different. Whereas national politics is largely about redistributive issues, these matters are essentially non-issues in local and regional government. Furthermore, if Peterson's 'unpolitics of redistribution' thesis is correct, subnational redistributive efforts - if these are made at all - are not likely to be instruments in the votemaximizing strategies of local and regional political parties. From this point of view, intermunicipal variations in party competition are expected to have no impact on variations in the redistributiveness of municipal policies.

Whether the prevalent 'redistribution' approach or Peterson's 'unpolitics of redistribution' thesis is more appropriate is essentially an empirical matter. In Section 1 of this paper I outline a theoretical model that is closely related to the prevalent 'redistribution' models. Hypotheses on the politics of redistribution in local government are deduced from this model. In Section 4 
these hypotheses are tested empirically on the basis of data on 342 Dutch municipalities. ${ }^{3}$ Before the results are presented, however, the measurement of the dependent variables are discussed (Section 2) and the statistical model employed in this study are introduced (Section 3). The paper is concluded by a discussion of the consequences of the results of this study for the prevalent 'redistribution' approach, and for Peterson's alternative.

\section{A simple model of redistributive policies}

\section{Basic elements of the model}

The model developed in this section is in many respects congenial to Downs' Economic Theory of Democracy (1957). Notwithstanding the similarities, however, the model differs from the Downsian approach in its assumptions on the motivation of political parties. Downs assumes that a political party can be considered as a unitary actor. This actor, according to Downs, is motivated by the rewards of elective office. In order to achieve this goal, the party has to be electorally successful. This reasoning leads Downs to a fundamental hypothesis: 'parties formulate policies in order to win elections, rather than win elections in order to formulate policies' (Downs 1957: 28). Downs' model implies that vote maximization is an appropriate goal for parties under all circumstances. It is, however, difficult to understand why a party enjoying a solid and stable majority of, say, 75 percent in a jurisdiction should try as hard to increase its share of the vote as a party in a neckand-neck-race.

Breton (1974) and Frey \& Lau (1968) develop models based on a more complex behavioural assumption which takes such considerations into account. According to Breton for example, the utility income of a party depends on two factors. First, it depends on whether the party is able to win the number or percentage of votes $(n)$ it wants to achieve in the election. Second, its utility income depends on the achievement of the party's ultimate goals (such as power or money, but also the satisfaction derived from the possibility to achieve personal political ideals). Breton assumes that parties maximize this utility function in such a way as to be sure that $n$ does not fall below a threshold value $n^{*}$. Frey \& Lau (1968) develop a similar model. They assume that, once the party's expected share of the vote exceeds a threshold value, a party will start to pursue its policy preferences. The approach these authors have chosen is not completely convincing however. These models are characterized by a marked discontinuity in the marginal utility of the expected share of the vote. All election results in which $n \geqslant n^{*}$ are equally satisfactory. And, all results in which $n<n^{*}$ are equally unsatisfactory. In the model proposed here, a party's appreciation of election results is not of such an all-or-nothing nature. It will be assumed that the economic law of decreasing marginal utility (Gossens' first law) applies to party vote 
shares as well. With an increasing share of the vote, the marginal utility of an extra one percent vote share, decreases. This is reflected in a decreasing priority of vote maximization and, following Frey \& Lau, an increasing priority for the pursuit of the party's policy preferences. ${ }^{4}$

An important reason to expect policy preferences to play a major role in determining party behaviour is the dependence of the elites in European mass-parties on a large rank-and-file. ${ }^{5}$ Following Laver \& Schofield (1990: 24), I assume that ' $\mathrm{t}$ ] he general rule is that the rank-and-file, more concerned with ideology and less in line for the other spoils of office, tend to resent the policy compromises necessary to enter coalition and hence to oppose them'. This 'general rule' also applies to compromises in the party's policy strategy for the sake of its electoral competitiveness (cf. Robertson 1976: 31-33, 39; Hirschman 1970: 72). This is not to say that the elite is bound hand and foot by the activists. Party members are aware that the realization of their preferences depends on the electoral success of their candidates. Within an 'area of acceptance' they will be willing to compromise in order to secure success at the polls. It seems plausible that the willingness of the rank-and-file to compromise will be smaller when the need to compete for votes is lower. On the other hand, once competition is keen, the necessity for parties to adjust their policies to the electoral preferences is higher and their willingness to compromise should accordingly be greater.

This reformulation of the Downsian model results in at least two interesting general propositions.

\section{Proposition A}

The closer electoral competition, the more party policies will be adjusted to match electoral preferences on these policies.

Proposition B

The less severe electoral competition, the more party policies will be adjusted to match the party's preferences on these policies.

In these propositions electoral competition is a variable conditioning the effects on government policies of the policy preferences of both electorate and parties.

\section{Towards testable hypotheses on redistributive policies}

These general hypotheses are rather imprecise. They leave several important questions on electoral preferences, party preferences and electoral competition unanswered. Two questions relate to the local electorate. First, what are the preferences of local electorates? Second, since popular attitudes are probably not unanimous, the question concerns whose preferences count for parties when there is a close competition for votes?

In order to answer the first question, an assumption has to be made about the motives underlying electoral behaviour. In line with Downs (1957: 36) it 
is assumed that voters seek to maximize the 'streams of utility derived from government activity'. Furthermore, voters are not supposed to be motivated primarily by the general long term interests of their community. A voter is assumed to have more intense feelings about his personal (economic) wellbeing or the situation of the social group with whom he identifies, than about the general (economic) condition of his community (cf. Downs 1957: 68, or Renaud \& Schram 1986: 345). Hence, it seems plausible that 'the economic bases for party affiliation must be sought in [the] area of income redistribution' (Stigler, 1973: 167). ${ }^{6} \mathrm{I}$ assume furthermore, that the preferences of a voter for redistributive policies are inversely related to the level of his income. Low income voters prefer a higher level of redistribution than high income voters. ${ }^{7}$ From this assumption it follows that, at the aggregate level, a strong association will exist between the municipal distribution of personal incomes and the distribution of voter preferences for redistributive policies. For this reason it seems legitimate to use the distribution of personal income as an approximation of the distribution of electoral preferences for redistributive policies. The shape of the personal income distribution is well documented. Generally, these distributions are single-peaked and skewed to the right.

But whose preferences count? In order to answer this question, a short exposition on the dynamics of electoral competition in multiparty systems is inevitable. In these systems there are two main forces driving the platforms of competing parties towards the centre of single-peaked distributions of electoral preferences. First, it is clear that moving closer to the centre of such a single-peaked distribution, a party will be able to win more votes than it will loose by alienating its off-centre support. Second, as Laver (1981: 136) points out, the anticipation of post-electoral coalitions leads to a 'tendency for the range of policies advocated in a multiparty system to contract at either extreme of the scale'. Parties generally do not advocate extreme policies because this would bring them in a rather uncomfortable position after the election. A party advocating extreme policies is either bound to keep its pre-election promises and be unacceptable as a partner in postelection coalitions. Or, it is bound to make large concessions on its extreme pre-election platform in order to become an acceptable partner, and thereby loose its credibility with the electorate. It should be emphasized however that these two centripetal forces do not lead to a complete convergence of parties towards the centre. An important force inhibiting complete convergence is the presence of the party's rank-and-file. These policy-oriented party members restrain the 'mobility' of party-platforms.

Nevertheless, these two centripetal forces confer a special status on the voters near the centre of the distribution of electoral preferences. Especially if competition is close, parties will be keen to be as responsive as possible to the preferences of the voters near the centre. As stated before, the municipal distribution of personal incomes is an acceptable approximation 


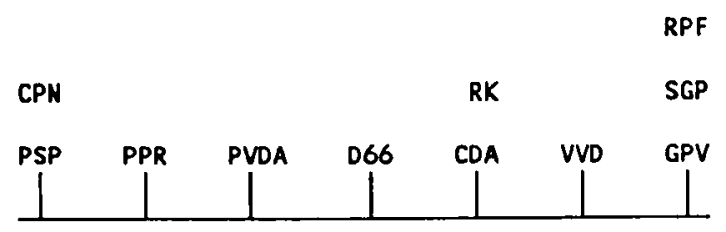

Fig. 1. Ranking of Dutch political parties on empirical policy-scale.

CDA - Christian Democratic Appeal; CPN - Communists; D66 - Democrats 66; GPV Reformed Political Association; PPR - Political Radicals; PSP - Pacifist Socialist; PVDA Social Democrats (Labour); RK - Roman Catholic Independents; RPF - Reformational Political Federation: SGP - Reformed Political Party: VVD - Conservative-Liberal Party.

of the distribution of the local electoral preferences for redistributive policies. The median is employed as a measure of centrality for the municipal distribution of personal income. ${ }^{8}$

Having considered electoral preferences, I now turn to several questions concerning policy preferences of political parties. First, it needs to be known what the preferences of the different local political parties are. Second, a closer look at the local decision making process is necessary to determine which parties are able to influence local policy decisions according to their preferences, to what extent.

Collecting complete data on the actual preferences of all of the local party branches in 342 municipalities was, for obvious reasons, beyond the scope of this research. Therefore, an assumption had to be made about these preferences. In this paper it is assumed that the ranking of the preferences for redistributive policies of the local branches of various national political parties in each of the municipalities in the sample is identical to the ranking of the policy preferences of the national political parties. The ranking presented in Figure 1, will be employed. ${ }^{9}$ The more to the left on this left-right continuum a party is positioned, the more it is in favour of highly redistributive policies.

Turning to the local decision making process, the voting power of parties, defined as the degree to which a party is able to determine the outcome of roll-call votes in a voting body such as the municipal council is crucially important. The voting power of a party depends not only on its relative number of seats but also on its opportunities to form majority coalitions (see e.g. Brams 1975; 175). These opportunities are to an important extent determined by the strategies parties choose. Referring to the earlier discussion of party behaviour it is plausible that parties will form coalitions that are not needlessly heterogeneous with regard to the policies advocated by their members. First, parties prefer relatively homogeneous coalitions because it is relatively easy to reach compromises that minimize the damage post-election compromising is bound to inflict upon the credibility of the parties with their electorate (Laver 1981: 135-137). Second, for essentially 
the same reasons, parties are thus able to sustain the support of their policyoriented rank-and-file.

In this paper a coalition is defined as 'relatively homogeneous' if it is what formal coalition theorists call a coalition of minimum range. A coalition is of minimum range if, assuming that parties are ordered on a left-right continuum, it has a minimum ordinal distance between its rightmost and leftmost member. ${ }^{10}$ On the basis of the party positions in Figure 1 for example, the coalitions $\{$ PvdA,D66,CDA $\},\{$ PvdA,CDA $\}$ and $\{\mathrm{CDA}, \mathrm{VVD}\}$ are of minimum range, but the coalition $\{\mathrm{PvdA}, \mathrm{D} 66, \mathrm{VVD}\}$ is not. If parties tend to form only these relatively homogeneous coalitions, spectacular differences between the distributions of seats and effective voting power may occur. These variations originate from differences in the strategic options to parties. In many voting-bodies the distribution of seats is such that the parties in the centre of the left-right spectrum are essential members (members whose defection would imply that the coalition would lose its required majority) of 'minimum range' coalition with both the parties to their left and with those to their right. Parties on the left or on the right of the spectrum, in contrast, are essential only in 'minimum range' coalitions including the centre party. In this paper, it is assumed that the bargaining power of a party in the negotiations preceding the decisive vote, and thereby its potential to influence policy decisions, is proportional to the number of times this party is an essential member of a majority minimum range coalition. This assumption underlies our index of voting power (VP), which is defined as:

$$
\mathrm{VP}=\mathrm{k}_{\mathrm{i}} / \sum \mathrm{k}_{\mathrm{i}}
$$

in which $k_{i}$ is the number of (majority) minimum range coalitions in which party $i$ is an essential member. ${ }^{11}$

In this study, the analysis of the effects of voting power and party preferences on local policies focuses on two of the three major Dutch political parties, the social democrats ( $\operatorname{PvdA})$ and the conservative party (VVD). This is because the voting power indices of the three main parties (including the CDA) typically sum to unity and the inclusion of the CDA is thus superfluous. ${ }^{12}$

It now is possible to phrase more precise hypotheses based on general propositions $\mathrm{A}$ and $\mathrm{B}$ above. With regard to electoral preferences it has been argued that, especially when competition is close, voters in the centre of the distribution of preferences are crucially important. As a measure of the central tendency of the distribution of preferences, the median was proposed. Furthermore, it was argued that the distribution of income could serve as an approximation of the distribution of electoral preference for redistributive policies. The higher a voter's income, the less supportive his or her attitudes to redistributive policies. The first hypothesis is thus: 
Hypothesis 1) The redistributiveness of municipal policies will be higher, the lower the median income in the municipality. This negative relation will be the stronger, the higher electoral competition in the municipality.

With regard to the policy preferences of the political parties, two more hypotheses can be formulated. If the voting power of either the PvdA or the VVD in a municipal council is relatively high, as measured by the index of voting power (VP), then the impact of that party's preferences on the outcome of policy decisions is considerable. In combination with what has been said about the location of these parties on the left-right scale it is expected that, all other things (notably the closeness of electoral competition) being equal, the higher the voting power of the social-democratic PvdA, the higher the level of redistributive government policies will be. Likewise, the voting power of the conservative-liberal VVD is expected to be inversely related to the redistributive efforts. The opportunities for a party to exploit its voting power fully however, depend on the level of electoral competition. As has been noted before, whenever electoral competition is intense, parties will have to make more concessions to the preferences of the electorate than they will when competition is less strong. In the latter case, parties have more room to pursue their ideological preferences. The preceding arguments lead to the formulation of two additional hypotheses:

Hypothesis 2) The redistributiveness of municipal policies will be higher, the higher the voting power of the social-democratic party $(P v d A)$ in a municipal council. This positive relation will be stronger the lower the electoral competition in a municipality.

Hypothesis 3) The redistributiveness of municipal policies will be lower, the higher the voting power of the conservative-liberal party $(V V D)$ in a municipal council. This negative relation will be stronger the lower the electoral competition in a municipality. ${ }^{13}$

Electoral competition is a conditioning variable in all three hypotheses. It is seen here as the degree to which a political party is able to formulate policies independent of the preferences of the local electorate and other political parties. Electoral competition is determined by both static and dynamic factors (cf. Stigler 1983: 34). A static factor stimulating competition is the effective number of parties. This number is determined by both the actual number of parties and by their relative size, in terms of the percentage of the total vote attracted. ${ }^{14}$ A relatively low effective number of parties leads to a low level of competition. In such a situation there is a predominance of one or two parties that are likely to have a firm grip on local political decision-making. Collusion to avoid the consequences of competition is more likely when the effective number of parties is smaller (cf. Olson 1965: 
43-52). At the same time, these parties will give a relatively low priority to vote maximization, given a decreasing marginal utility of votes. A second, dynamic, factor related to competition is electoral volatility. ${ }^{15}$ Electoral volatility is defined as the average change in the voting shares of parties in consecutive elections. The lower volatility, the more stable a party's 'marketshare', and the less it need to worry about mobilizing the vote. For these reasons, a higher level of volatility implies more intense electoral competition.

\section{The measurement of 'redistributiveness'}

In selecting the two policy areas considered in this study, two redistributive policies were selected, both characterized by substantial municipal autonomy vis-à-vis central government. ${ }^{16}$

The first is housing policy and more specifically housing allocation policies in the council and privately rented sector. In most Dutch municipalities the management of the rented sector is the primary responsibility of independent housing associations (the privately rented sector is only of marginal importance). The primary task of the housing associations is to take care for adequate and affordable accommodation for low income groups. Allocation policies, a major responsibility of these associations, determine the access of various groups to the council sector. In this area, as in the privately rented sector, social objectives and considerations of economically sound housing management are often difficult to reconcile. Those 'most in need' are not always attractive tenants from a housing management perspective. Because of their relevance for the housing opportunities of low-income groups, many local authorities have set up policies to control the registration and allocation rules of the housing associations and private landlords. Municipal registration and allocation criteria generally emphasize social, medical and other 'needoriented' criteria. For the purpose of this research a scale has been constructed to measure the degree of municipal control over the allocation policies of the housing associations and private landlords. ${ }^{17}$ These municipal controls are meant to increase the housing opportunities of low-income groups at the expense of more wealthy citizens. Thereby the city becomes more attractive for low-income groups, while at the same time it becomes more difficult for more prosperous people to find accommodation in the city.

The second policy area relates to local taxation. The Dutch local real estate tax has two rates, one for owners and one for users (mostly tenants). Under the assumption that owners of real estate are generally wealthier than non-owners, some local authorities employ these rates to redistribute wealth. They fix relatively high rates for owners and low or moderate rates for users of real estate. The ratio of owner and user-rates (the tax rates ratio) indicates the redistributiveness of the local real estate tax. ${ }^{18}$ 


\section{The statistical analysis of conditional relations}

The main methodological problem in this research is the statistical analysis of the conditional relations between the variables in the hypotheses. For instance, in Hypothesis 1 the effects of median income on the dependent variable, are hypothesized to depend upon the value of the level of electoral competition. The standard linear-additive regression model is inappropriate for testing such conditional hypotheses, since in this statistical model the effects of the regressors are assumed to be independent. A widely used method for handling conditional relations, often referred to as 'interactions', is the addition of a 'multiplicative' term to the regression equation. ${ }^{19}$ In the most simple case of a conditional relation between two regressors $\left(X_{1}\right.$ and $X_{2}$ ) this method implies that a multiplicative term, the product of $X_{1}$ and $\mathrm{X}_{2}$, is added to the regression equation. As becomes clear when Equation 2 is rewritten as $2 \mathrm{a}$, the effect of $\mathrm{X}_{1}$ (e.g. median income) on $\mathrm{Y}$ (e.g. the tax rate ratio) depends on the value of $X_{2}$ (e.g. electoral volatility).

$$
\begin{aligned}
& \mathrm{Y}=\mathrm{a}+\mathrm{b}_{1} * \mathrm{X}_{1}+\mathrm{b}_{2} * \mathrm{X}_{2}+\mathrm{b}_{3} *\left(\mathrm{X}_{1} * \mathrm{X}_{2}\right)+\mathrm{E} \\
& \mathrm{Y}=\left[\mathrm{a}+\mathrm{b}_{2} * \mathrm{X}_{2}\right]+\left[\mathrm{b}_{1}+\mathrm{b}_{3} * \mathrm{X}_{2}\right] * \mathrm{X}_{1}+\mathrm{E}
\end{aligned}
$$

Friedrich (1982) has demonstrated that, once the conditional nature of this equation is recognized, the interpretation of the coefficients in Equation (2a) is straightforward. The first term between square brackets in Equation (2a) is the intercept of a function representing the relation between $Y$ and $X_{1}$. This term gives the value of the dependent variable if $X_{1}$ equals zero. ${ }^{20}$ The second term between brackets represents the 'slope' of the relation between $\mathrm{Y}$ and $\mathrm{X}_{1}$ (or the 'effect' of $\mathrm{X}_{1}$ on $\mathrm{Y}$ ). This second term is in part determined by the value of $X_{2}$. The coefficient $b_{1}$ represents the effect on $Y$ of a change in $X_{1}$ if and only if $X_{2}$ equals zero, while $b_{3}$ gives the change in the effect of $\mathrm{X}_{1}$ on $\mathrm{Y}$ due to a change in $\mathrm{X}_{2}$. The interpretation of coefficients in equations with more than one conditioning variable and/or more independents is not inherently different from this simple model. This will become evident in the discussion of the results in Section 4.

\section{Results}

The regression results relevant to the tests of the hypotheses for each of the dependent variables $\left(\mathrm{Y}_{\mathrm{i}}\right)$ are contained in the Table $1 .{ }^{21}$ The estimates of the model coefficients are grouped in such a way as to demonstrate the conditional effects of the electoral preferences (median income; $X_{1}$ ) and the voting power of the PVDA $\left(X_{2}\right)$ and the VVD $\left(X_{3}\right)$ clearly. In the following subsections the implications of these regression results for the three hypotheses developed in Section 1 will be discussed. ${ }^{22}$ 
Table 1. The conditional effects of median income, voting power PvdA and voting power VVD on the control of housing allocation and the tax rate ratio

\begin{tabular}{|c|c|c|c|c|c|c|}
\hline \multirow[b]{2}{*}{ Intercept } & \multicolumn{3}{|c|}{ Equation for $Y_{1}$} & \multicolumn{3}{|c|}{ Equation for $\mathrm{Y}_{2}$} \\
\hline & $\{-2.81$ & $\begin{array}{l}+2.68 * X_{4} \\
(3.51)\end{array}$ & $\begin{array}{l}\left.-0.01 * \mathrm{X}_{5}\right] \\
(3.54)\end{array}$ & {$[-0.93$} & $\begin{array}{l}-0.13 * \mathrm{X}_{4} \\
(0.58)\end{array}$ & $\begin{array}{l}\left.+0.004 * X_{5}\right] \\
(4.59)\end{array}$ \\
\hline $\begin{array}{l}\text { Conditional } \\
\text { effect } X_{1}\end{array}$ & $\begin{array}{l}{[1.99} \\
(1.88)\end{array}$ & $\begin{array}{l}-1.18 * X_{4} \\
(3.78)\end{array}$ & $\begin{array}{l}\left.+0.004 * X_{5}\right] * X_{1} \\
(3.84)\end{array}$ & $\begin{array}{l}{[0.89} \\
(2.64)\end{array}$ & $\begin{array}{l}+0.04 * \mathrm{X}_{4} \\
(0.42)\end{array}$ & $\begin{array}{l}\left.-0.0016 * X_{5}\right] * X_{1} \\
(4.35)\end{array}$ \\
\hline $\begin{array}{r}\text { Conditional } \\
\text { effect } X_{2}\end{array}$ & $\begin{array}{c}{[-0.08} \\
(3.50)\end{array}$ & $\begin{array}{l}+0.01 * \mathrm{X}_{4} \\
(2.52)\end{array}$ & $\begin{array}{l}\left.+0.00005 * X_{s}\right] * X_{2} \\
(2.15)\end{array}$ & $\begin{array}{l}{[-0.009} \\
(1.69)\end{array}$ & $\begin{array}{l}+0.005 * \mathrm{X}_{4} \\
(3.32)\end{array}$ & $\begin{array}{l}\left.-0.00001 * \mathrm{X}_{5}\right] * \mathrm{X}_{2} \\
(1.80)\end{array}$ \\
\hline \multirow[t]{2}{*}{$\begin{array}{r}\text { Conditional } \\
\text { effect } X_{3}\end{array}$} & $\begin{array}{l}{[-0.004} \\
(0.13)\end{array}$ & $\begin{array}{l}+0.02 * X_{4} \\
(2.82)\end{array}$ & $\begin{array}{l}\left.-0.00008 * \mathrm{X}_{5}\right] * \mathrm{X}_{3} \\
(2.51)\end{array}$ & $\begin{array}{l}{[-0.017} \\
(2.32)\end{array}$ & $\begin{array}{l}+0.007 * X_{4} \\
(3.76)\end{array}$ & $\begin{array}{l}\left.-0.00001 * X_{5}\right] * X_{3} \\
(1.63)\end{array}$ \\
\hline & \multicolumn{3}{|c|}{$\begin{array}{l}\mathrm{R}_{\text {adj. }}^{2}=0.17 \\
\text { Number of weighted cases }=527\end{array}$} & \multicolumn{3}{|c|}{$\begin{array}{l}\mathrm{R}_{\mathrm{ndj}}^{2}=0.16 \\
\text { Number of weighted cases }=460\end{array}$} \\
\hline
\end{tabular}

$\mathrm{Y}_{1}=$ allocation control; $\mathrm{Y}_{2}=$ tax rate ratio; $\mathrm{X}_{1}=$ median income; $\mathrm{X}_{2}=$ PVDA voting power; $X_{3}=$ VVD voting power; $X_{4}=$ effective number of parties; $X_{5}=$ electoral volatility.

Hypothesis 1: The effects of median income. Hypothesis 1 states that the negative relation between median income $\left(\mathrm{X}_{1}\right)$ and the redistributiveness of municipal policies will be more negative when competition is keen than if competition is relatively less close. The second row of Table 1 (conditional effect of $\mathbf{X}_{1}$ ) shows how median income affects the redistributiveness of local policies, and how this effect is conditioned by electoral competition. Relevant $\mathrm{t}$-values are specified between brackets below the equations. It is clear that the effect of median income on the two dependent variables changes with changing combinations of the values of both indicators for electoral competition $\left(\mathrm{X}_{4}\right.$ and $\left.\mathrm{X}_{5}\right)$.

On theoretical grounds it was expected that the hypothesized negative conditional effect of median income on the control of allocation policies $\left(\mathrm{Y}_{1}\right)$ would be stronger when competition is more intense. From Table 1 it is evident that both the number of effective parties and electoral volatility significantly affect the impact of median income on housing allocation control. The sign of the coefficient for the effective number of parties $\left(\mathrm{X}_{4}\right)$ is negative as predicted. The effect of electoral volatility $\left(\mathrm{X}_{5}\right)$ is positive, not negative as hypothesized.

With regard to the tax-rate ratio $\left(Y_{2}\right)$, it was also expected that the hypothesized negative effect of median income on the redistributiveness of taxation would be stronger, the more intense was party competition. The results in Table 1 show that the coefficient of the effective number of parties $\left(\mathrm{X}_{4}\right)$ is insignificant, indicating that the impact of this variable on the relation between median income and the tax rate ratio is negligible. Electoral volatility $\left(\mathrm{X}_{5}\right)$, however, significantly affects the relation of median income and the tax-rate ratio. Moreover, the sign of the coefficient is negative as expected.

From these results it has to be concluded that there is only scant evidence in support of the first hypothesis. The effect of median income on the 
redistributiveness of two local policies proved to be dependent on the intensity of electoral competition. But, of the four coefficients, only two were both in the direction predicted by the model developed in Section 1, and significant.

So far I have concentrated on the impact of competition on the conditional effect of median income and said nothing about the direction and strength of this conditional effect. This effect can be computed by substituting specific values for $\mathrm{X}_{4}$ and $\mathrm{X}_{5}$ in the relevant part (i.e. the second row of Table 1 of the two regression equations). If this is done it becomes clear that the conditional effect of median income is not consistently negative as was hypothesized. Empirically, a significant negative relation was only found for specific combinations of values of the 'conditioning' variables. ${ }^{23}$ Not only the strength but also the direction of the relation between median income and the dependent variable, was affected by electoral competition.

Hypothesis 2: The effects of PVDA voting power. Hypothesis 2 states that, the stronger the voting power of the social democratic PVDA $\left(\mathrm{X}_{2}\right)$, the more redistributive that local policies $\left(\mathrm{Y}_{\mathrm{i}}\right)$ will be. This positive relation is expected to be stronger when electoral competition is relatively weak. Therefore, it is expected that the coefficients of the competition variables in the equations representing the conditional effect of PVDA voting power on the dependent variables (third row in Table 1) will be negative. The results in Table 1 clearly indicate that both the number of effective parties and electoral volatility significantly affect the impact of PVDA voting power on the control of housing allocation $\left(Y_{1}\right)$. But, contrary to what was expected, the most strict controls are found where a relatively powerful PVDA is under tough competition (statistically, the signs of the coefficients are positive and not negative as hypothesized). The results for the tax-rate ratio $\left(Y_{2}\right)$ do not conform to theoretical expectations either. Although the sign of the coefficient for electoral volatility is negative as expected, this estimate is insignificant. The effect of the number of effective parties is significant, but the coefficient representing this effect has the 'wrong' sign.

The overall picture looks much the same as for Hypothesis 1. Although the effect of PVDA voting power on both redistributive policies under study is conditioned by at least one aspect of electoral competition, the predictive power of the theoretical model developed in Section 1 proved to be poor. The sign of four coefficients was predicted. Empirically, none of these predictions proved to be correct. These unexpected results also affect the accuracy of the prediction with regard to the hypothesized positive conditional effect of PVDA voting power on the redistributiveness of local policies. It was expected that only the strength of this relation would vary with the level of electoral competition. Empirically, however, not only the strength but also the sign of the effect of PVDA voting power varied for various combinations of values for the two competition variables. The expected positive effect only occurred for specific combinations of values of the two competition variables. 
Hypothesis 3: The effects of VVD voting power. According to Hypothesis 3 the redistributiveness of municipal policies will be lower, the higher the voting power of the conservative-liberal party $\left(\mathrm{VVD} ; \mathrm{X}_{3}\right)$ in the municipal council. This negative relation is expected to be stronger, the less intense is electoral competition. Table 1 (third row, equation for $\mathrm{Y}_{1}$ ) allows an empirical assessment of this hypothesis for the case of the control of allocation policies. As was predicted theoretically, the effect of VVD voting power on the control of allocation policies becomes less negative, the higher the effective number of parties $\left(\mathrm{X}_{4}\right)$. Moreover, the coefficient of this variable is significant. The effect of electoral volatility $\left(\mathrm{X}_{5}\right)$ is significant as well. But this effect runs in the 'wrong' direction.

The effects of party competition on the relation of VVD voting power and the tax rate-ratio are also presented in Table 1 (third row, equation for $\left.Y_{2}\right)$. It is clear from the table that the effective number of parties $\left(X_{4}\right)$ conditions the effect of the VVD voting power on the dependent variable as hypothesized. The coefficient of this conditioning variable is positive and significant. The effect of electoral volatility $\left(X_{5}\right)$, however, contradicts the theoretical predictions. This variable has a negative, though insignificant, coefficient.

All-in-all, Hypothesis 3 is not corroborated. Electoral competition in both cases conditions the effect of the VVD voting power on the redistributiveness of municipal policies. But the pattern of the effects of both electoral volatility and the effective number of parties does not generally conform to theoretical expectations. The signs of four coefficients for the conditioning variables were predicted and only two of these predictions proved to be correct. Partly due to these unexpected results, the hypothesized negative effect of VVD voting power on the redistributiveness of local policies is not found either. This expectation was only borne out for specific combinations of values of the two competition variables.

\section{Concluding remarks}

According to many political scientists (re)distributive issues are at the heart of politics. In this vein, many students of subnational politics have focused on the politics of redistribution as their central concern. A popular hypothesis among these scholars states that 'office-seeking' local politicians compete for electoral popularity by offering the relatively numerous less well-to-do specific benefits at the expense of more affluent citizens. Peterson (1981) has challenged this approach. According to him redistributive issues are essentially the business of central government. In the local political arena these issues are conspicuous by their absence. He claims that local politicians will refrain from major redistributive efforts lest they lose their edge in intermunicipal economic competition.

This paper has evaluated a number of propositions on the politics of 
redistribution in local government. The model from which these propositions were derived starts from the assumption that redistributive issues are key elements in the politics of local government. An attempt was made to explain intermunicipal variations in redistributive policies on the basis of differences in the competitiveness of local party systems. An unequivocal corroboration of these hypotheses would cast serious doubts on the Peterson thesis.

Empirical research in Great Britain seems to support the main thrust of the logic underlying this model. Sharpe \& Newton (1984: 176-204), on the basis of an extensive empirical study, reject Peterson's model and stress the importance of ideological and party system variables. First, they find that Labour domination of municipal politics has a significant (though not very strong) association with 'redistributive and socially ameliorative services'. Second, their research lends support to the idea that, the more competitive the party system, the more parties are competing for the median voter and the more cautious they are in pursuing their party ideology. Conversely, once competition is less severe, parties are more inclined to follow party ideology in shaping municipal policies.

The theoretical model presented in Section 1 builds on similar notions. Three hypotheses derived from this model were tested empirically on data for 342 Dutch municipalities. The Dutch results did not corroborate the hypotheses. Too be sure, the redistributiveness of municipal policies was affected by the electoral preferences (median income) and the voting power of social democrats (PVDA) and liberals (VVD). Furthermore, these effects proved to be conditional rather than general in nature: the relationships varied with the closeness of electoral competition. These findings clearly suggest that party politics and political competition, contrary to what Peterson suggests, do affect the redistributiveness of municipal policies. Nevertheless, the performance of the theoretical model is to be considered rather poor. The major defect of this model was its inability to explain the ways in which electoral volatility and the effective number of parties affect the strength and direction of these relations. In all, 12 predictions on the effect of the two competition variables were made. In nine of these cases a significant conditioning effect was found empirically, but in only four cases did this significant effect go in the expected direction. This is by all standards a poor success rate.

All-in-all, the findings in this research pose a theoretical dilemma. On the one hand, it is obvious that the support for the proposed 'redistribution' model is scant. But, on the other hand, this failure should not too readily be interpreted as supportive of Peterson's 'unpolitics of redistribution'-argument. Some of the findings in this study cast doubt on his thesis as well. Whereas, for instance, it seems plausible that intermunicipal economic competition would tend to level out major differences in the redistributiveness of municipal policies, we found rather substantial intermunicipal variations in redistributiveness. ${ }^{24}$ Besides, the present study clearly shows that the competitiveness of the party-system affects (as part of a conditional effect) 
the level of municipal redistribution. These findings, even though they do not lend support to the 'redistribution model' proposed earlier either, are difficult to reconcile with Peterson's thesis. This is because intermunicipal variations in party-competition are expected in Peterson's model to have no impact on variations in the redistributiveness of municipal policies. The findings of this study are consistent with those of scholars (such as Sharpe \& Newton 1984), who expect intermunicipal differences in redistribution to originate in the competitiveness of the local party system and the resulting variations in the conditions confronting politicians competing for the popular vote. These results suggest that, rather than abandoning the study of local redistribution as a non-issue in subnational politics, an effort should be made to develop a better theoretical understanding of the ways in which competition and party politics shape these policies.

\section{Acknowledgements}

I am indebted to R.A.G. van Puijenbroek for his assistance with the data analysis and C.P. Middendorp, M. Pedersen, B. Steunenberg and two anonymous referees for their comments on an earlier draft of this paper.

\section{Notes}

1. This redistribution hypothesis builds on earlier work by Key \& Lockard. A pioneer study in this tradition is Dawson \& Robinson (1963). Some examples of later studies on subnational redistribution are Cnudde \& McCrone (1969), Fry \& Winters (1970), Lineberry (1977), Plotnick \& Winters (1985), and Hoggart (1987).

2. Peterson concedes that some local authorities with a rather strong tax base can afford some redistribution. But cities with relatively many poor and needy citizens, and a correspondingly weak fiscal base, simply cannot afford substantial redistributive efforts. What is more important, however, is that neither type of city has an 'economic' incentive to pursue redistributive goals.

3. For this research data on 342 Dutch municipalities are used. These 342 cases form a disproportionally stratified and systematic sample of the population of 810 Dutch municipalities in 1979 , the year in which the sample was taken.

4. This conceptualizatlon implies as Stigler (1972) has argued, that the 51 percent result is not seen as marking a special discontinuity. Furthermore, this model starts from rather different assumptions than Peterson's model. Peterson employs a model based on essentially benevolent politicians, motivated by a sense of responsibility for their community. In contrast the model developed here assumes that parties are motivated by a mixture of 'office-seeking' and 'policy-seeking'.

5. The elite cannot ignore the rank-and-file for two reasons. Firstly, the membership nominates the candidates. Secondly, the support of the party membership is essential in the conduct of a modern election campaign.

6. Of course these assumptions mark a crucial difference with Peterson's approach. In Peterson's model voters are not short-sightedly pursuing their short-term interests in practicing 'pocketbook-voting', but are sensitive to the long-term economic interests of their community. 
7. This formulation implies neither that low income voters prefer a complete levelling of incomes nor that high income recipients are totally opposed to any redistribution whatsoever. First, the enthusiasm of low-income individuals is tempered because they realize the negative macro-economic effects of radical levelling. Second, there may be a more or less general consensus among citizens, including the well-to-do, that differences in personal incomes exceeding a certain level are socially unacceptable. This second argument implies that higher income groups, out of a sense of 'public regardingness', might support some redistribution of income, even though they will be the ones who will pay for such policies. This assumption is supported by Szirmai (1986: 97-98), who concludes on Dutch data for 1980 that the lower the income category of a respondent, the stronger his tendency to equalize'. Nevertheless, and in line with the previous argument, Szirmai also finds that, even among the high income groups, there is support for a somewhat more modest level of income redistribution.

8. This variable is defined operationally as the median of the distribution of personal income (before taxation) in the municipality in 1978. The mode of the distribution would have heen a better measure, since this is the point of the distribution where most of the voters are located. In the case of income distributions, however, as Comanor (1976) has shown, the distance between the mode and the median is generally relatively small. It should be emphasized that the selection of the median as the measure of centrality does not imply that I endorse the hypothesis that party programmes completely converge on the median.

9. The construction of this empirical policy scale is based primarily on a survey by Van Schuur (1984, 1986) on the belief systems of delegates to conferences of the four major Dutch parties (CDA, PvdA, VVD and D66). The political orientations of these delegates are dominated by the traditional left-right dimension. According to Van Schuur: 'the left or "progressive" side of this continuum is associated with a desire to lessen inequality among people, regions and countries, and to protect both those who are vulnerable and the environment. The right or "conservative" side is associated with a concern for safety, freedom of the individual, and the lessening of state control' (1984: 212). Since, Van Schuur's study relates only to the four major parties, I had to rely on additional information based on the content analyses of party platforms by Laver \& Budge (as reported in Laver \& Schofield 1990: 262) and expert judgments reported by Castles \& Mair (1984) for the placement of the other parties. In addition, the position of the Roman Catholic independent parties was assumed to coincide with the position of the CDA. These local Catholic parties can be considered an integral part of the subculture of the dominant Catholic 'zuil' (Kuiper \& Dittrich 1991: 58). A detailed report on the construction of this scale is available upon request. This ranking was used in the computation of an index of voting power (see below) as well.

10. For details on the concept of 'range' and 'ordinal distance', see De Swaan (1973: 92). In my analyses I followed the approach described by De Swaan. In these analyses both minimum range coalitions containing an unnecessary member (i.e. a member in the coalition that could be expelled from the coalition without making the coalition a losing one; such coalitions are often referred to as connected minimum range coalitions) as well as minimum range coalitions without such an actor (unconnected minimum range) were admitted.

11. This measure is based on the so-called Banzhaf index. The original index (see Brams 1975: 164-167) however, has been adjusted to take the assumed preference of parties for relatively homogeneous (minimum range) coalitions into account.

12. At the 1978 elections D66 was only a minor political force (it commanded less than 2 percent of the seats in Dutch municipal councils).

13. It might he argued that the locus of local power is not the municipal council, but that local policies are essentially determined by the distribution of voting power in the municipal executive. When the local executive is not formed according to the traditional consociational 'rules' (proportional representation) but in a majoritarian way, important differences in the distribution of voting power in the council and the executive might occur. Therefore, I computed voting power indices for the parties represented in the municipal executive as 
well. Two versions of the hypotheses were tested, the version presented in this paper, and a variant based on the composition of the municipial executive. The results of both these tests were essentially the same. Therefore, I only present the results for the municipial council in this paper.

14. This measure is formally defined as $\left[1 / \Sigma\left(p_{i}^{2}\right)\right]$, in which $p_{i}$ is the proportion of the total vote for party i (Laakso \& Taagpera 1979: 4). It has a straightforward interpretation. If in a polity with four actual parties, one party has an enormous majority (say 95 percent) the number of effective parties will be almost equal to one. If on the other hand these four parties each attract 25 percent of the vote, the actual number of parties equals the effective number of parties. This index has been computed for each of the municipalities in my sample, on the basis of official results of the 1978 municipal elections. The $p_{i}$ 's refer to the proportion of the valid votes (not including abstentions) and was computed over all parties participating in the election. The official election statistics put votes cast for independent lists in two residual categories. If two or more parties belonging in the same residual category are participating in a municipality, this will result in an underestimation of the actual number of effective parties.

15. Electoral volatility (cf. Pedersen 1983) is defined here as the average change in the proportion of total number of valid votes (not including abstentions) cast for a party bloc in the municipal elections of 1970, 1974 and 1978. Six party-blocs were distinguished - extreme left, centre left, christian-democrats (including catholic independent lists), conservative liberal, extreme right and local independents. Blocs were used instead of separate parties in order to facilitate comparisons overtime. The average is computed for each of the municipalities in the sample on the basis of both four-year differences (1970-1974 and 1974$1978)$ as well as on the eight-year difference (1970-1978). Formally this measure is defined as:

$\operatorname{VOLATILITY}\left(\mathrm{X}_{5}\right)=\sum\left[\left|\mathrm{P}_{\mathrm{i} ; 70}-\mathrm{P}_{\mathrm{i} ; 74}\right|+\left|\mathrm{P}_{\mathrm{i} ; 70}-\mathrm{P}_{\mathrm{i} ; 74}\right|+\left|\mathrm{P}_{\mathrm{i} ; 70}-\mathrm{p}_{\mathrm{i} ; 78}\right|\right] / \mathrm{N} * \mathrm{~K}$

in which $\mathrm{P}_{\mathrm{i}: 7^{*}}=$ voting share of party-bloc $\mathrm{i}$ in the $197 \cdot$ municipal elections

$\mathrm{K}=$ the number of elections $(\mathrm{K}=3)$

$\mathrm{N}=$ the number of party-blocs $(\mathrm{N}=6)$

16. In general Dutch local government enjoys only limited formal and fiscal autonomy (e.g. Hoogerwerf 1980). However, Dutch local government, more than elsewhere, is involved in the implementation of numerous central government policies in a wide variety of policy areas (cf. Toonen 1987, 1990; Denters, de Jong \& Thomassen 1990). This general practice is referred to as co-governance ('medebewind'). These co-governance arrangements in many instances allow for considerable de facto local autonomy (cf. Toonen 1987, 1990). In general, municipal opportunities to affect the distribution of monetary income are limited (though not always negligible). The municipal potential to allocate benefits to low-income groups in all kinds of nonmonetary policies (that also fall under my definition of redistributive policies; see Introduction), however, is considerable. In conclusion, and to remove a source of possible misunderstandings, I would like to stress that this paper does not start from the assumption that most of the redistribution in Dutch society is through municipal policies. What I do claim is that municipalities have certain nontrivial powers that enable them to pursue redistributive policies in their own right.

17. The six-point scale is constructed on the basis of five dichotomous items. These items form a strong Mokken scale (total scalability $\mathrm{H}_{\mathrm{t}}=0.54$; All coefficients for the scalibility of the items $\mathrm{H}_{\mathrm{i}}>\mathbf{0 . 4 0}$ ). For a detailed report on the construction of this scale I refer to Denters, 1987: 260-262. The Mokken scaling procedure is described in Mokken (1970). The items, presented in increasing order of municipal control are: (a) Is the municipality informed about the conditions for registration as a househunter employed by housing associations? (b) Does the municipality enter into negotiations with housing associations to influence conditions for registration? (c) Does the municipality determine conditions for registration unilaterally? (d) Do housing associations and private landlords completely control the 
allocation of cheap rented accomodation? (e) Is the allocation of all rented accomodation concentrated in the hands of the municipality?

18. Notwithstanding the fact that local taxes comprise less than ten percent of municipal revenues, the local real estate tax is by far the most important of these local sources of revenue. I selected this area for two reasons. First, the real estate tax per capita is not inconsiderable in money terms and highly visible. The per capita burden of this tax, in 1979, varied between hfl. 36 and hfl. 248 (Coumans 1981: 40). Of course the burden per household will be substantially higher. For the real estate tax a specific tax assessment is sent to all tax payers once a year. This makes this tax highly visible. Second, previous research has indicated that redistributive motives play an important role in explaining the tax rate ratio (Coumans 1981; De Looff 1980).

19. An alternative to this method is to split up the sample into subgroups according to the scores of the municipalities on the conditional variables (in this context, two aspects of competition). This alternative method has two major drawbacks. Firstly, if the conditional variable is continuous (as our two conditional variables are) regression results might be heavily affected by the arbitrary decision on the selection of the cutting points. Secondly, if we want to test hypotheses on the simultaneous effects of two conditional variables, the sample would have to be split up in at least four, relatively small, subsamples. The method employed in this paper avoids both problems. An important objection against the multiplicative term is based on the observation that the multiplicative term (e.g. $\mathrm{X}_{1} * \mathrm{X}_{2}$ ) typically correlates highly with either or both of its constituent variables. Multicollinearity can lead to unstable estimates. In this research a special indirect estimation technique is employed to circumvent any problems due to multicollinearity. This method, which builds on the work of Smith \& Sasaki (1979) and Tate (1984), was developed by Denters \& Van Puijenbroek (1989). For the estimation of conditional regression models with this indirect method a computer program, INTERACT, was developed by R.A.G. van Puijenbroek.

20. First, this intercept depends on the value of the coefficient $a$. This coefficient $a$ represents the value of $\mathrm{Y}$ if not only $\mathrm{X}_{1}$ but also $\mathrm{X}_{2}$ equals zero. Second this intercept depends on the value of $X_{2}$. The size of the 'effect' of $X_{2}$ on this intercept is represented by the coefficient $b_{2}$.

21. Because we do not have a simple random sample the use of statistical tests for inferential purposes is illegitimate. In this research I used test-statistics as - admittedly rather arbitrary criteria for substantive significance. In the analyses the size of the t-values (a critical t-value of 2.00 or more) is used as such a criterion. This corresponds to the 2.5 percent significance level for a one-tailed t-test. This rather stringent criterion was adopted to compensate for the effects of a weighting procedure employed to correct for the underrepresentation of small municipalities in our disproportionally stratified sample. In the evaluation of the results I rely on the unstandardized regression coefficients and the standard errors of these estimates (remember: $t$-value is ratio of regression coefficient and its standard error) rather than on the $\mathrm{R}^{2}$. For the evaluation of theoretical predictions the squared multiple correlation coefficient is not very useful (cf. Achen 1977).

22. Both regression models were controlled for major violations of the assumptions of the regression model (normal distribution of the residuals and homoscedasticy). Except for minor infringements no violations of the assumptions of normally distributed residuals and homoscedasticy were detected. After thi removal of 1 case for the $Y_{1}$-model, and 6 cases from the $\mathrm{Y}_{2}$-model, the regression results were robust.

23. For the computation of the t-values for these conditional-effect estimates see Friedrich (1982).

24. The coefficient of variation for the control of allocation was 0.56 (mean 2.55 ; standard deviation: 1.43 ) and 0.27 for the tax rate ratio (mean: 1.43 ; standard deviation: 0.39 ).

\section{References}

Achen, C.H. (1977). Measuring representation: Perils of the correlation coefficient, American Journal of Political Science 21: 805-815. 
Brams, S.J. (1975). Game theory and politics. New York: The Free Press.

Breton, A. (1974). The economic theory of representative government. Chicago: Aldine.

Castles, F.G. \& Mair, P. (1984). Left-right scales, some 'expert' judgments, European Joumal of Political Research 12: 73-88.

Cnudde, C.F. \& McCrone, D.J. (1969). Party competition and welfare politics, American Political Science Review 63: 858-866.

Comanor, W.S. (1976). The median voter rule and the theory of political choice, Journal of Public Economics 5: 169-177.

Coumans, P.A.H.H. (1981). Gemeentelijk inkomsten-en reinigingsbeleid: Verslag van een vergelijkend onderzoek. Enschede: University of Twente.

Dawson, R.E. \& Robinson, J.A. (1963). Inter-party competition, economic variables and welfare policies in American states, Journal of Politics 25: 265-289.

Denters, B. (1987). Partijen, kiezers en gemeentelijk beleid: Een empirische toetsing van een politiek-economische theorie. Amsterdam: CT Press.

Denters, S.A.H., Jong, H. de \& Thomassen, J.J.A. (1990). Kwaliteit van Gemeenten: Een onderzoek naar de relatie tussen de omvang van gemeenten en de kwaliteit van het lokaal bestuur. 's-Gravenhage: VUGA.

Denters, B. \& Puijenbroek, R.A.G. van (1989). Conditional regression analysis: Problems, solutions and an application, Quality \& Quantity 23: 83-108.

Downs, A. (1957). An economic theory of democracy. New York: Harper \& Row.

Friedrich, R.J. (1982). In defense of multiplicative terms in multiple regression equations, American Journal of Political Science 26: 797-833.

Frey, B. \& Lau, L.J. (1968). Towards a mathematical model of government behaviour, Zeitschrift für Nationalökonomie 28: 355-380.

Fry, B.R. \& Winters, R.F. (1970). The politics of redistribution, American Political Science Review 64: 508-522.

Gray, V. (1976). Models of comparative state politics: A comparison of cross-sectional and time-series-analyses, American Journal of Political Science 20: 235-257.

Hirschman, A.O. (1970). Exit, voice and loyalty: Responses to decline in firms, organizations and states. Cambridge, MA: Harvard University Press.

Hoggart, K. (1987). Does politics matter? Redistributive policies in English cities 1949-74, British Journal of Political Science 17: 359-384.

Hoogerwerf, A. (1980). Relaties tussen centrale en lokale overheden in Nederland, Beleid en Maatschappij 6: 330-346.

Jacob, H. \& Lipsky, M. (1971). Outputs, structure and power: An assessment of changes in the study of state and local politics, pp. 14-40 in: R.I. Hofferbert \& I. Sharkansky (eds.), State and urban politics, readings in comparative public policy. Boston: Little, Brown and Co. (Originally published in Journal of Politics, 30 (1968): 510-538).

Kuiper, W. \& Dittrich, K.L.L.M. (1991). Breukvlakken in het politieke landschap in Limburg: De Limburgse kiezer tussen 1945-1990, pp. 55-67 in: A.F.A. Korsten \& W. Kuiper (eds.), Limburg kiest: Ontwikkelingen in de lokale politiek rondom de gemeenteraadsverkiezingen van maart 1990. Zeist: Kerckebosch.

Laakso, M. \& Taagepera, R. (1979). 'Effective' number of parties, a measure with application to West-Europe, Comparative Political Studies 12: 3-27.

Laver, M. (1981). The politics of private desires: The guide to the politics of rational choice. Harmondsworth: Penguin Books.

Laver, M. and Schofield, N. (1990). Multiparty government: The politics of coalition in Europe. Oxford: Oxford University Press.

Lineberry, R.L. (1977). Equality and urban policy: The distribution of municipal public services. Beverly Hills: Sage.

Looff, J.P. de (1983). De doorwerking van het draagkrachtbeginsel in de gemeentelijke onroerend goed-belastingen, Financieel Overheidsbeheer 55: 8-12.

Mokken, R.J. (1970). A theory and procedure of scale-analysis: With applications in political research. The Hague/Paris: Mouton. 
Olson, M. (1971). The logic of collective action. Cambridge, MA: Harvard University Press.

Pedersen, M.N. (1983). Changing patterns of electoral volatility in European party systems 1948-1977, pp. 29-66 in: H. Daalder \& P. Mair (eds.), Western European party systems: Continuity and change. Beverly Hills: Sage.

Peterson, P.E. (1981). City limits. Chicago: Lniversity of Chicago Press.

Plotnick, R.D. \& Winters, R.F. (1985). A politico-economic theory of income redistribution, American Political Science Review 79: 458-473.

Renaud, P.S.A. \& Schram, A.J.H.C. (1986). Verkiezingen en economie, Economisch Statistische Berichten 71: 344-348.

Robertson, D. (1976). A theory of party-competition. London: John Wiley.

Schuur, H. van (1984). Structure in political beliefs: A new model for stochastic unfolding with an application to European party activists. Amsterdam: CT Press.

Schuur, W.H. van (1986). Structuur in politicke opvattingen van Nederlandse partijactivisten: Dominantie van de links-rechts dimensie, pp. 195-216 in: Jaarboek 1985, Documentatiecentrum Nederlandse Politieke Partijen. Groningen: Rijksuniversiteit Groningen.

Smith, K.W. \& Sasaki, M.S. (1979). Decreasing multicollinearity: A method for models with multiplicative functions, Sociological Methods \& Research 8: 35-56.

Stigler, G.J. (1972). Economic competition and political competition, Public Choice 12: 91106.

Stigler, G.J. (1973). General economic conditions and national elections, American Economic Review 63: 160-167.

Stigler, G.J. (1983). The organization of industry. Chicago: University of Chicago Press.

Swaan, A. de (1973). Coalition theories and cabinet formations: A study of formal theories of coalition formation as applied to nine European parliaments after 1918. Amsterdam: University of Amsterdam, Ph. D. thesis.

Szirmai A. (1986). Inequality observed: A study of attitudes towards income inequality. Groningen: University of Groningen, Ph.D. thesis.

Tate, R.L. (1984). Limitations of centering of interactive models, Sociological Methods \& Research 13: 251-271.

Toonen, Th.A.J. (1987). Denken over Binnenlands Bestuur: Theorieën over de gedecentraliseerde eenheidsstaat bestuurskundig beschouwd. "s-Gravenhage: VUGA.

Toonen, Th.A.J. (1990). The unitary state as a system of co-governance: The case of the Netherlands, Public Administration 68: 281-296.

Address for correspondence: B. Denters, Faculty of Public Policy and Public Administration, University of Twente, P.O. Box 217, 7500 AE Enschede, The Netherlands.

Phone: (53) 899111. 